\title{
Морфологічні зміни міокарда міжшлуночкової перегородки протягом першіх годин після алкогольної септальної абляції у хворих із гіпертрофічною кардіоміопатією (два клінічні спостереження)
}

\author{
Захарова В. П. ${ }^{1}$, Руденко К. В. ${ }^{1}$, Невмержицька Л. О. ${ }^{1}$, Балабай А. А. ${ }^{2}$, \\ Дорофєєва С. І. ${ }^{1}$, Чумак О. С. ${ }^{1}$ \\ ${ }^{1}$ ДУ «Національний інститут серцево-судинної хірургії імені М. М. Амосова НАМН України» (Київ) \\ ${ }^{2}$ Національний медичний інститут імені О. О. Богомольця (Київ)
}

\begin{abstract}
Алкогольна септальна абляція є альтернативним методом лікування гіпертрофічної кардіоміопатії. У літературі не знайдено даних відносно характеру змін міокарда в перші години після алкогольної септальної абляції.

Мета роботи - описати дані вивчення морфологічних зміни міокарда у двох хворих з обструктивною гіпертрофічною кардіоміопатією через 1 та 10 годин після проведення алкогольної септальної абляції.

Методи: макроскопія; мікроскопія гістологічних препаратів, забарвлених гематоксиліном і еозином, пікрофуксином за ван Гізоном, фукселіном за Вейгертом, а також методом MSB у модифікації Зербіно-Лукасевич.

Результати. У мікросудинах зареєстровано зміни стінок, які пов'язані зі спиртовою коагуляцією їхніх структур. Просвіти артерій і артеріол були обтуровані «тінями» еритроцитів або дрібними згустками крові, що спричинило ішемічне ушкодження кардіомоіцитів. Вихід спирту за межі капілярів супроводжувався коагуляційним некрозом навколишніх кардіомоіцитів. Через 10 годин після алкогольної септальної абляції в зонах ураження були наявні лейкоцитарні інфільтрати.
\end{abstract}

Ключові слова: гіпертрофічна кардіоміопатія, міжшлуночкова перегородка, алкогольна абляція, морфологія.

Гіпертрофічна кардіоміопатія (ГКМП) - генетично детерміноване первинне захворювання міокарда 3 аутосомно-домінантним типом успадкування, яке характеризується асиметричною гіпертрофією міокарда, збільшенням площі стулок мітрального клапана (MK) з подальшим порушенням проведення збудження і зміною внутрішньосерцевої гемодинаміки. Ця патологія реєструється в загальній популяції у $0,2-0,5 \%$ випадків. Природний перебіг захворювання пов'язаний із високим ризиком раптової смерті (3-6\% хворих із ГКМП на рік). Виділяють обструктивну і необструктивну форму ГКМП залежно від наявності звуження у вихідному тракті лівого шлуночка (ВТЛШ). Обструктивна ГКМП характеризується більш вираженими клінічними проявами. До недавнього часу було запропоновано декілька підходів до iii лікування: медикаментозна терапія, електрофізіологічне лікування (імплантація DDD штучного водія ритму серця (ШВРС)), ендоваскулярне - алкогольна септальна абляція (АСА) та хірургічне лікування. Медикаментозна терапія в пацієнтів з обструктивною ГКМП як метод монолікування наразі переважно не використовується у зв'язку з незадовільними безпосередніми та віддаленими результатами. Метод двока- мерної електрокардіостимуляції також не виправдав очікувань, оскільки віддалені результати в цієї когорти пацієнтів не відрізняються від ефекту плацебо [2]. Хірургічний метод вважається «золотим стандартом» лікування обструктивної ГКМП, однак він не може використовуватися в пацієнтів, стан яких пов'язаний із високим кардіохірургічним ризиком. Крім того, успішне хірургічне лікування ГКМП можливе лише в медичних центрах, де працює висококваліфікована мультидисциплінарна команда спеціалістів. Алкогольна септальна абляція є альтернативним методом для пацієнтів, у яких не може бути застосоване хірургічне лікування. Віддалені та безпосередні результати в більшості пацієнтів після АСА є хорошими [2, 3]. Так, колектив авторів із Національного інституту серцево-судинної хірургії імені М. М. Амосова [2] у своїй науковій праці, присвяченій вивченню результатів ACA у 123 пацієнтів, спостерігав у віддаленому періоді зниження систолічного градієнта тиску з $91,7 \pm 8,3$ мм рт. ст. до $\leq 30$ мм рт. ст. у $81 \%$ пацієнтів. A. Batzner та співавт. [3] у своєму дослідженні, у яке ввійшло 952 пацієнти, визначили в безпосередньому періоді спостереження зниження систолічного градієнта тиску у ВТ ЛШ з 63,9 $\pm 38,2$ мм рт. ст. до 
$33,6 \pm 29,8$ мм рт. ст. у спокої та з $104,6 \pm 44,0$ мм рт. ст. до $56,5 \pm 41,0$ мм рт. ст. при проведенні проби Вальсальви. У 98,6\% випадків ці пацієнти досягли 5-річної точки контролю без значущих кардіоваскулярних подій.

Наукові роботи з дослідження морфологічних змін міокарда міжшлуночкової перегородки (МШП), які відбуваються в різні періоди після проведення АСА, не численні, грунтуються на одиничних спостереженнях, тому не відображають усіх ланок патогенезу. Так, A. L. Baggish та співавт. описують зміни в міокарді після проведення АСА у 4 пацієнтів у терміни від 2 днів до 14 місяців [4]. Найбільш ранні зміни в міокарді після проведення ACA наразі в літературі не описані. У нашому центрі було два летальні випадки - через 1 та 10 годин після АСА.

Мета роботи - описати дані вивчення морфологічних зміни міокарда у двох хворих з обструктивною ГКМП через 1 та 10 годин після проведення АСА.

Матеріали і методи. Хворий Г., 55 років (помер через 1 годину після проведення АСА), поступив із клінічними ознаками, які відповідають III ФК за NYHA: скарги на задишку та загрудинні болі при незначному фізичному навантаженні, серцебиття і загальну слабкість. На ЕКГ специфічні зміни не відзначалися. Дані ЕхоКГ: систолічний градієнт тиску (СГТ) у ВТЛШ 116 мм рт. ст., товщина МШП - 2,2 см, регургітація на MK - 35\%. За результатами коронаровентрикулографiï (КВГ) у коронарних артеріях гемодинамічно значущих звужень не виявлено. Під час проведення АСА у пацієнта після введення 2 мл етанолу в септальну гілку (СГ) ПМШГ ЛКА виникла синусова брадикардія, яка перейшла в асистолію. Реанімаційні заходи були ефективними, вдалося відновити гемодинаміку на 1 годину, в подальшому знову виникла асистолія, яка призвела до смерті.

Хвора К., 66 років (померла через 10 годин після проведення АСА), звернулася в клініку зі скаргами на виражену задишку при незначному фізичному навантаженні та іноді в спокої, слабкість, набряки нижніх кінцівок, напади серцевої астми. На ЕКГ - рубцевий кардіосклероз по передній стінці лівого шлуночка. При ЕхоКГ: СГТ у ВТЛШ - 42 мм рт. ст., товщина МШП - 2,4 см, регургітація на MK - 28\%, у перикарді по задній стінці - 0,9 см рідини, ознаки вираженої діастолічної дисфункції міокарда. За даними КВГ, коронарні артерії інтактні. Виконано АСА 3-ї СГ ПМШГ лівої коронарної артерії. Через 1 годину після процедури відзначено погіршення гемодинаміки з наростаючими ознаками шоку. Через 10 годин лікування у відділенні інтенсивної терапії хвора померла. При патоморфологічному дослідженні встановлено, що причиною смерті стала кровотеча з підключичної артерії в місці виконання пункції для постановки центрального венозного катетера.

Макроскопічне вивчення серця та інших органів проведено під час аутопсії, далі досліджували гістологічні препарати, отримані з різних ділянок МШП і вільних стінок лівого шлуночка (ЛШ) серця. Парафінові зрізи виготовляли за загальноприйнятою методикою і забарвлювали їх гематоксиліном та еозином (для оглядової мікроскопії), пікрофуксином за ван Гізоном (для диференціювання м'язових і колагенових волокон), фукселіном за Вейгером на еластин, методом MSB у модифікації Зербіно-Лукасевич. Остання методика дозволяє виявити фібрин різного ступеня зрілості, а також оцінювати функціональний стан кардіоміоцитів (КМЦ) [1].

Результати. При морфологічному дослідженні серця у хворого Г. відмічено потовщення базального відділу МШП. Ендокард у цій ділянці досягає товщини 1,5 мм за рахунок розростання колагенових і еластичних волокон, між якими визначаються тонкі прошарки, що складаються з дистрофічно змінених м'язових клітин (рис. 1А, 1Б).

Тяжі фіброзної тканини від ендокарда поширюються в товщу міокарда (рис. 1А). У глибоких шарах міокарда відмічаються інші зміни, характерні для ГКМП: гіпертрофія КМЦ, яка в багатьох ділянках переходить
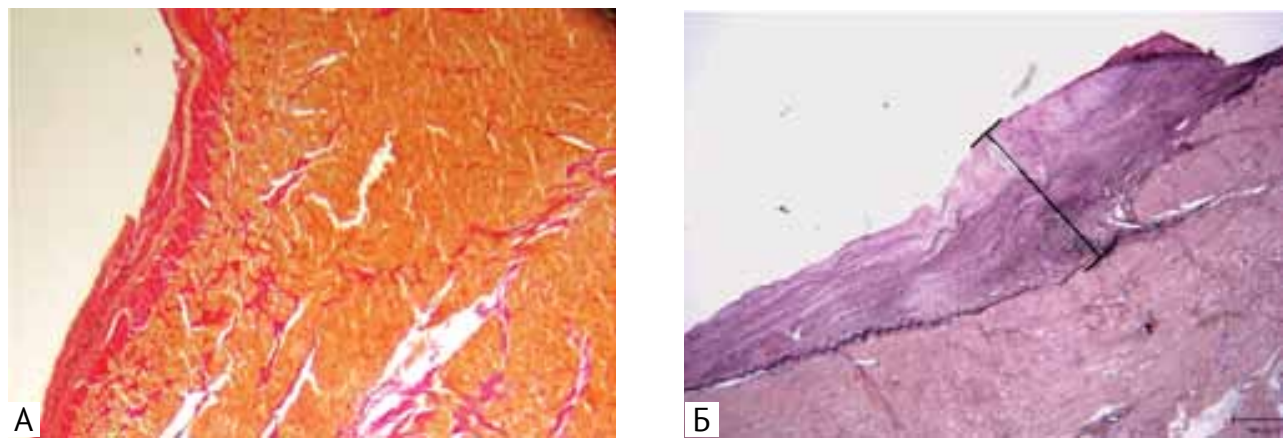

Рис. 1. Хворий Г. Фіброз ендокарда субаортальної частини МШП, що поширюється по інтерстицію в товщу міокарда: $A$ - фарбування пікрофуксином за ван Гізоном, збільшення х40; Б - фарбування фукселіном за Вейгертом, збільшення х20 


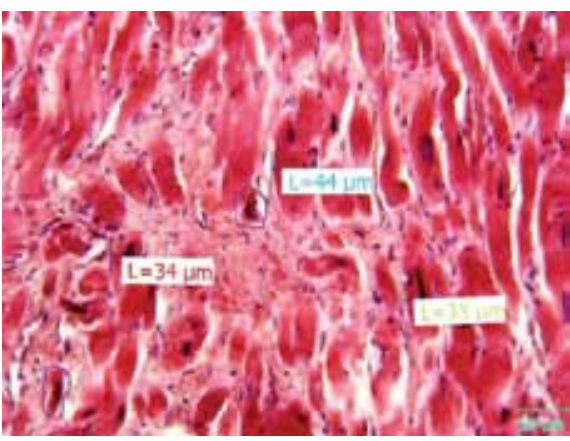

Рис. 2. Хворий Г. Базальна частина МШП. Гіпертрофія КМЦ із замісним фіброзом. Фарбування гематоксиліном і еозином, збільшення х200
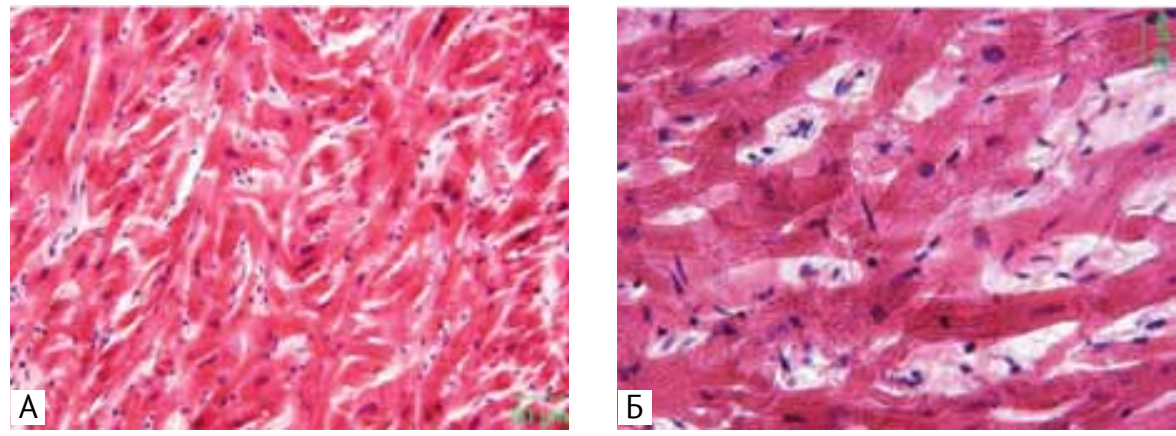

Pис. 3. Хворий Г. Disarray у базальній частині МШП. Фарбування гематоксиліном та еозином. Збільшення А х200, Б х400 у стадію декомпенсації з ознаками дистрофії, апоптозу і розвитку замісного фіброзу (рис. 2).

Крім того, як і в більшості випадків ГКМП, у хворого Г. у глибоких шарах МШП, особливо в базальному відділі, візуалізуються зони дезорієнтації КМЦ (disarray) (рис. 3А, ЗБ). При цьому в багатьох міоцитах на великому збільшенні можна було побачити ефект інтрацелюлярної різноспрямованості міофібрил (рис. 3Б).

Але в МШП хворого Г., крім особливостей будови, характерних для ГКМП, були також інші зміни, які можна пов'язати з процедурою спиртової абляції. У проксимальному відділі СГ ПМШГ ЛКА, у яку вводили спирт, просвіт був заповнений коагульованими елементами плазми і склеєними, зафіксованими спиртом, оболонками лізованих еритроцитів. На цьому фоні диференціювалася підвищена кількість лейкоцитів, які, вірогідно, потрапили в зону ушкодження із центрального коронарного кровотоку (рис. 4А). Більш дрібні артерії в зоні абляції повністю обтурували згустки крові з лізованими еритроцитами. Деякі автори визначають такі внутрішньосудинні депозити як атромбоцитарні тромби [4]. Проте в ділянках руйнування судинних стінок формувалися справжні тромби (рис. 4Б).

Найдрібніші артерії та артеріоли були повністю обтуровані свіжими тромбами у зв'язку з блокадою кровотоку в проксимальному відділі цього судинного басейну.

Унаслідок стаза крові виникає гіпоксія КМЦ, найбільш ранніми ознаками якої є перескорочення м'язових клітин (рис. 5Б). Контрактура одних саркомерів може спричинити розрив міоцитарного волокна в сусідній ділянці з блокадою поширення імпульсу збудження і зниженням скорочувальної здатності ушкодженого м'язового пучка.

Іншою найбільш ранньою ознакою гіпоксії міокарда вважається так звана хвиляста дегенерація КМЦ (рис. 6). У хворого Г. ця ознака була наявна в препаратах із середнього і навіть апікального відділу більшою мірою, ніж у базальних сегментах. Скоріше за все, це пов'язано з тим, що АСА проводилася не через 1-шу СГ ПМШГ ЛКА у зв'язку з їі дуже вузьким устям, а че-
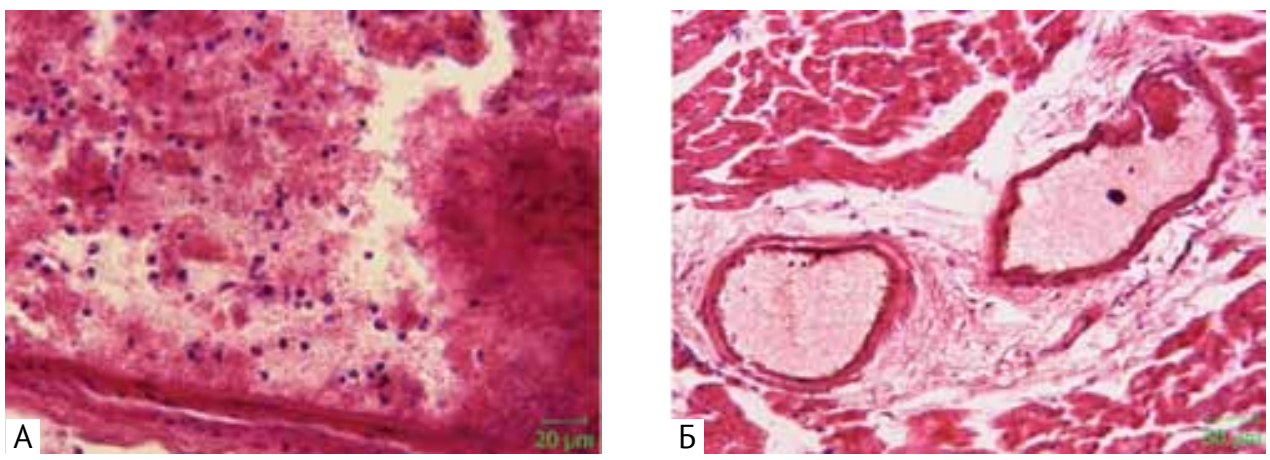

Рис. 4. Хворий Г.Артерії МШП у зоні спиртової абляції, фарбування гематоксиліном та еозином:

$A$ - фрагмент артерії з коагульованими елементами плазми і еритроцитів у просвіті; збільщення х400; 5 - дрібні артерії, справа зверху - руйнування судинної стінки з формуванням тромбу; 


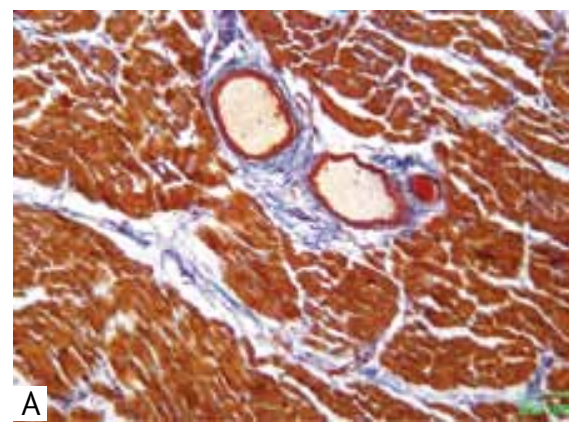

Рис. 5. Хворий Г.Дрібні артерії та артеріоли МШП у зоні спиртової абляції. Фарбування MSB: A - дві інтрамуральні артерії, заповнені елементами коагульованої крові; збільшення х100; Б - затромбовані артеріоли, КМЦ із зонами перескорочення

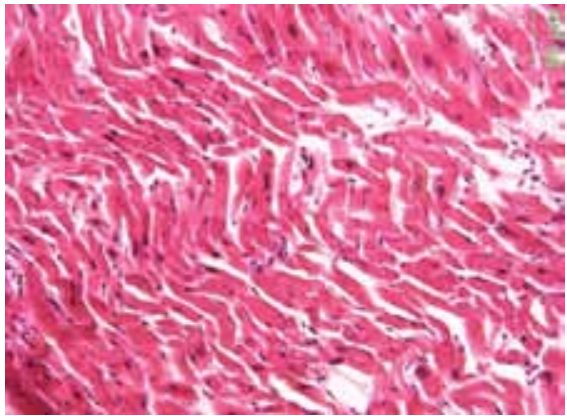

Рис. 6. Хворий Г. Хвиляста дегенерація КМЦ МШП. Фарбування гематоксиліном та еозином, збільшення х100 рез 2-гу. Крім того, у цьому спостереженні особливістю будови ПМШГ ЛКА було те, що дистальніше устя 2-ої СГ вона згиналася майже під прямим кутом і, деформуючись, входила в міокард.

На гістологічному зрізі видно, як у цьому місці КМЦ у вигляді своєрідного сфінктера охоплюють описувану судину, що під час систоли (особливо в умовах ендоваскулярних маніпуляцій) могло лімітувати проходження крові до міокарда середніх і верхівкових сегментів МШП.

Але, крім ранніх ознак гіпоксії КМЦ, у середніх і базальних сегментах МШП хворого Г. були також зміни, які можна пов'язати скоріше з безпосереднім впливом спирту на КМЦ. Це відмічалося в ділянках міокарда, у яких капіляри були вільні від крові, але при цьому вони не тільки не спалися при обробці препаратів, але навпаки: їх просвіт виглядав перерозтягненим (рис. 8А). Руйнування стінки таких капілярів супроводжувалося коагуляційним некрозом прилеглих до них КМЦ (рис. 8Б). Ймовірно, що в цих капілярах кров була витіснена спиртом, який їх фіксував, але при потраплянні в інтерстиціальний простір він чинив безпосередню токсичну дію на КМЦ i, меншою мірою, на сполучну тканину ендомізію.

Мікроскопічне вивчення міокарда МШП хворої К. показало, що через 10 годин після проведення спиртової абляції в зонах гіпоксичного перескорочення міокарда формувалися поля дрібнофрагментованих КМЦ на фоні розрихленої набряком сполучної тканини ендомізію (рис. 9, 10).

В інших ділянках домінували ознаки міоцитолізису. При цьому збережені КМЦ були перерозтягненими, ix ядра мали паличкоподібну форму (рис. 10).

Крім посилення ознак альтерації м'язової тканини, в препаратах, отриманих через 10 годин після абляції, було видно прояви реакції організму на ушкодження у вигляді лейкоцитарної інфільтрації. Найбільш вираженим цей процес був у перифокальних зонах навколо колатеральних судин (рис. 11А) і в прошарках набряклої сполучної тканини (рис. 11Б).

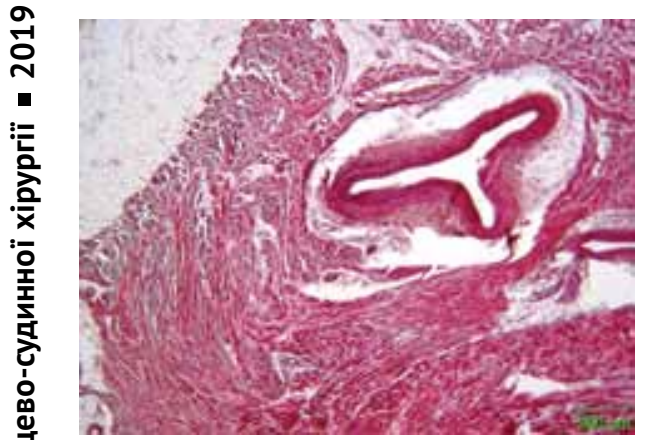

Рис. 7. Хворий Г. ПМШГЛКА занурена в міокард і оточена циркуляторно розташованими пучками КМЦ. Фарбування гематоксиліном і еозином, збільшення х20
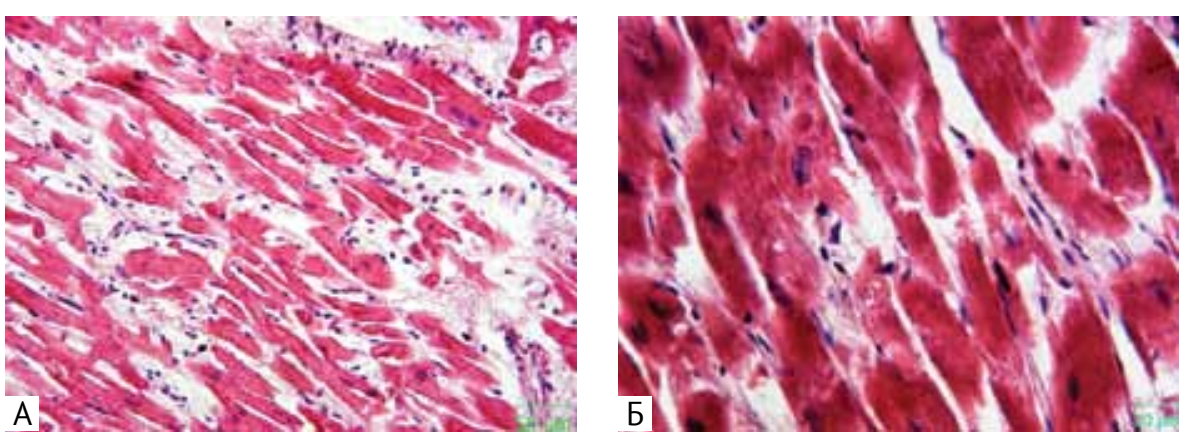

Рис. 8. Хворий Г. Міокард МШП. Фарбування гематоксиліном та еозином: A - капіляри розширені прозорою рідиною, порушення цілісності міоцитарних волокон, збільшення х200; Б - коагуляційний некроз КМЦ у ділянці руйнування капіляра, що був заповнений прозорою рідиною, перескорочення саркомерів, збільшення х400 


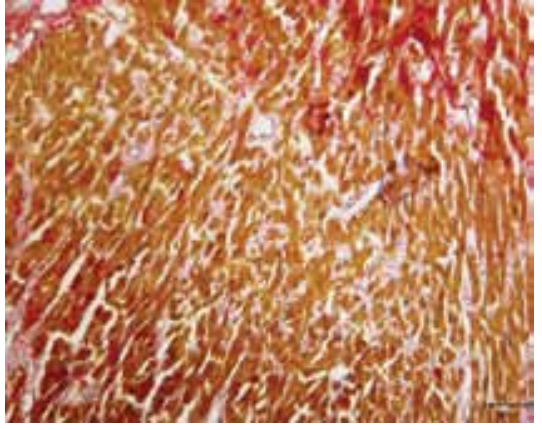

Рис. 9. Хвора К. Фрагментація КМЦ і набряк строми в ділянці перескорочення міокарда. Фарбування MSB, збільшення х100

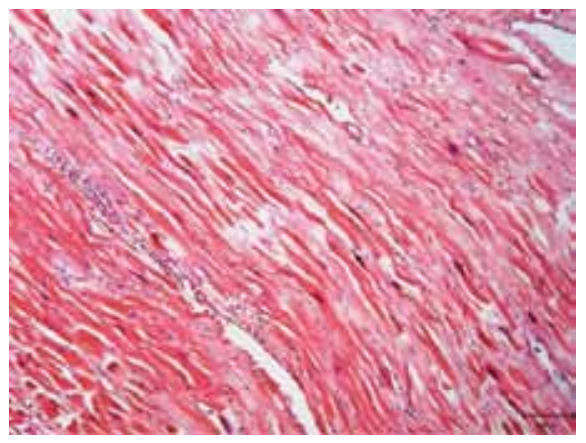

Рис. 10. Хвора К. Перерозтягнення і лізис КМЦ із лейкоцитарною інфільтрацією. Фарбування гематоксиліном і еозином, збільшення х100
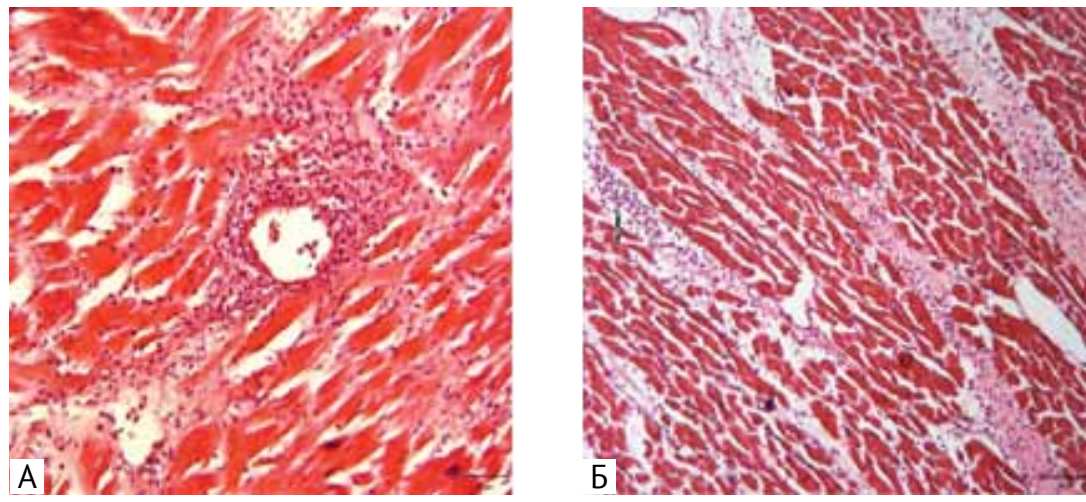

Рис. 11. Хвора К. Міокард на межі з вогнищами ушкодження. Лейкоцитарна інфільтрація: A - периваскулярна, збільшення х200; 5 - в інтерстиціальних сполучнотканинних прошарках. Фарбування гематоксиліном та еозином, збільшення х100

У ділянці ушкодження зустрічалися також дрібні судини, які мали велику кількість лейкоцитів. Але в просвітах таких судин диференціювали також згустки коагульованої крові, а судинна стінка була більшою або меншою мірою зруйнована. Це сприяло міграції лейкоцитів у периваскулярну тканину (рис. 12А) і до локусів ушкодження КМЦ (рис. 12Б).

Більш великі гілки артерії, в яку введено спирт, були повністю обтуровані конгломератом склеєних еритроцитів, які можливо було визначити тільки завдяки блідому фарбуванню їхніх мембран (рис. 13).
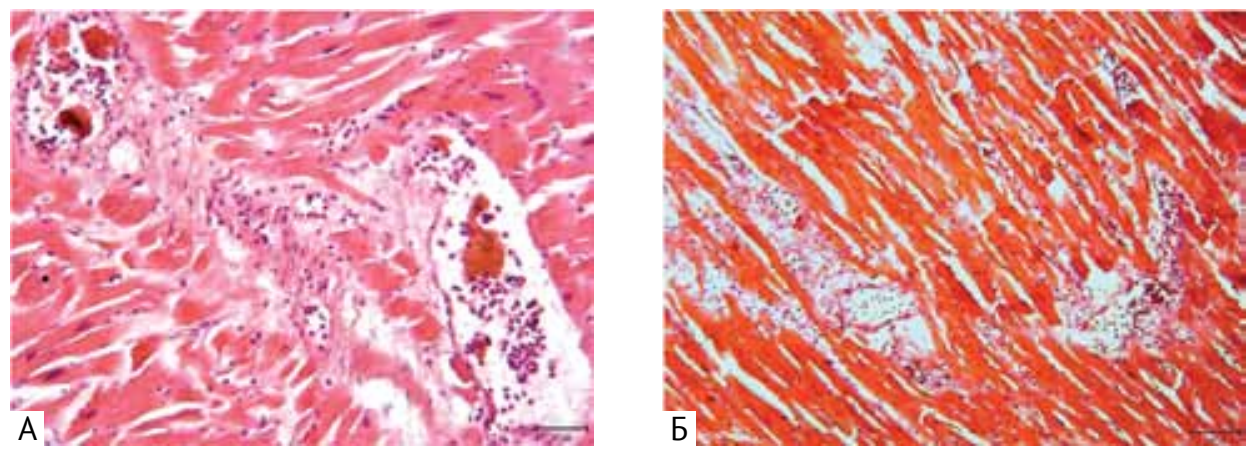

Рис. 12. Хвора К. Міокард у вогниші ушкодження. Фарбування гематоксиліном і еозином: A - дрібні судини зі зруйнованими стінками, у просвіті лейкоцити і згустки коагульованої крові, збільшення х200; Б - лейкоцитарна інфільтрація: периваскулярно і навколо ушкоджених КМЦ, збільшення х100 


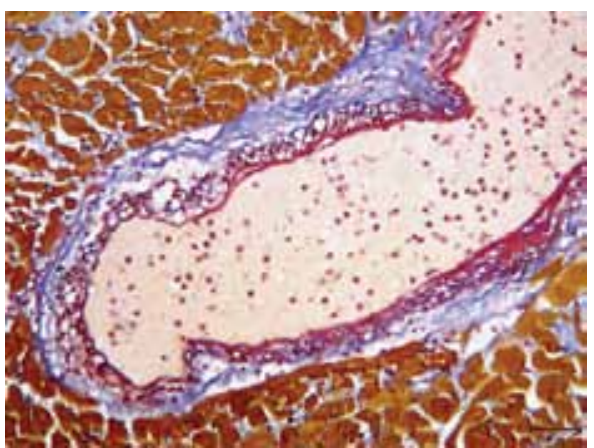

Рис. 13. Хвора К. Інтрамуральна артерія з обтурованим просвітом, структури стінок дистрофічно змінені і набряклі. Фарбування за методом MSB, збільшення х200

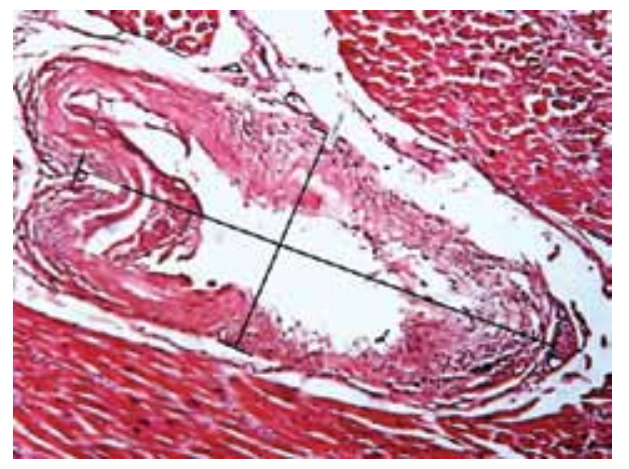

Рис. 14. Хвора К. Устя 1-ої СГ ПМШГЛКА. Зруйновані стінки судини в результаті механічної травми. Фарбування гематоксиліном та еозином, збільшення х200
На фоні змінених еритроцитів були розсіяні нечисленні лейкоцити, які також знаходились у стані дистрофії. Стаз крові в просвіті артерії супроводжувався набуханням i вогнищевою деструкцією внутрішніх еластичних мембран іiі стінок і різко вираженим інтраі перицелюлярним набряком медії. Зі сторони адвентиції стінка артерії інфільтрувалася лейкоцитами, що посилювало процес альтерації.

В 1-ій СГ ПМШГ ЛКА, поблизу зони введення в неї спирту, інтима судини і внутрішній шар медії на значній протяжності були порушені з поширенням дефектів тканин на різну глибину стінки артерії. В адвентиції ушкодженого сегмента відмічалася помірна лейкоцитарна інфільтрація. Просвіт артерії був вільний від крові та деформований у результаті інвагінації в нього однієї ділянки стінки. Ці зміни можна пов'язати з механічною травмою судини при проведенні спиртової абляції. Але описані ушкодження не слід розцінювати як ускладнення лікарської тактики, оскільки метою цієї процедури є саме блокада кровотоку по СГ ПМШГ ЛКА для ішемізації гіпертрофованого міокарда базальної частини МШП.

\section{Висновки}

1. У міокарді МШП обох хворих були наявні морфологічні зміни, характерні для ГКМП (гіпертрофія КМЦ, фіброз ендокарда та інтерстицію, фігури disarray).
2. Процедура АСА спричиняє ушкодження артеріальних стінок і внутрішньосудинну коагуляцію крові 3 подальшою гіпоксією міокарда.

3. Вихід алкоголю за межі капілярів чинить пряму токсичну дію на КМЦ.

4. Через 10 годин після АСА в міокарді відмічається лейкоцитарна реакція на ушкодження гістологічних структур.

\section{Література}

1. Захарова ВП, Руденко КВ, Руденко ЕВ, Левчишина EB, Третьяк AА. Использование метода MSB в модификации Зербино-Лукасевич для диагностики морфофункционального состояния миокарда. Патологія. 2010;7(2):105-6.

2. Руденко КВ, Невмержицька ЛО, Трембовецька ОМ, Фанта СМ, Лазоришинець ВВ. Алкогольна септальна абляція - сучасна альтернатива в лікуванні хворих 3 обструктивною формою гіпертрофічної кардіоміопатії. Вісник серцево-судинної хірургії. 2016;2(25):93-6.

3. Batzner A, Pfeiffer B, Neugebauer A, Aicha D, Blank C, Seggewiss H. Survival After Alcohol Septal Ablation in Patients With Hypertrophic Obstructive Cardiomyopathy. J Am Coll Cardiol. 2018 Dec 18;72(24):3087-94. DOI: 10.1016/j.jacc.2018.09.064.

4. Baggish AL, Smith RN, Palacios I, Vlahakes GJ, Yoerger DM, Picard MH, Lowry PA, et al. Pathological effects of alcohol septal ablation for hypertrophic obstructive cardiomyopathy. Heart. 2006 Dec;92(12):1773-8. DOI: 10.1136/hrt.2006.092007.

\title{
Morphological Changes on the Interventricular Septal Myocardium within the First Hours after Alcohol Septal Ablation in Patients with Hypertrophic Cardiomyopathy
}

\author{
Zakharova V. P. ${ }^{1}$, Rudenko K. V. ${ }^{1}$, Nevmerzhytska L. O. ${ }^{1}$, Balabai A. A. ${ }^{2}$, Dorofeeva S. I. ${ }^{1}$, Chumak O. S. ${ }^{1}$ \\ ${ }^{1}$ National M. M. Amosov Institute of Cardiovascular Surgery National Academy of Medical Sciences of Ukraine (Kyiv) \\ ${ }^{2}$ Bogomolets National Medical University (Kyiv)
}

The surgical method is the gold standard for the treatment of obstructive HCM. However, it cannot be used in patients whose condition causes a high cardiosurgical risk. In addition, successful surgical treatment of HCM is possible only in medical centres, where there is a highly qualified multidisciplinary team of specialists. 
ASA is an alternative treatment for HCM. The literature does not reflect myocardial changes in the first hours after ASA.

Objective: to describe the data on the study of morphological changes in the myocardium of two patients with obstructive HCM one and ten hours after ASA.

Patients: patient G., 55 years old, NYHA class III, pressure gradient in the LV outflow tract $-116 \mathrm{~mm} \mathrm{Hg}$, IVS thickness of $2.2 \mathrm{~cm}$, mitral regurgitation $-35 \%$. During ASA, bradycardia developed, what turned into asystole. Haemodynamics was restored. However, an hour later, recurrent asystole occurred, which led to death.

Patient K., 66 years old, with clinical signs corresponding to NYHA class III, LV systolic pressure gradient $-49 \mathrm{~mm} \mathrm{Hg.,}$ IVS thickness $-2.4 \mathrm{~cm}, 28 \%$ mitral regurgitation. One hour after ASA, signs of hemodynamic deterioration appeared, which resulted in death in 10 hours. The autopsy showed that the cause of death was bleeding from the subclavian artery at the puncture site for the central venous catheter.

Methods: macroscopy, microscopy of histological samples stained with hematoxylin and eosin, Van Gieson's picrofuchsin, Weigert's fuchselin, by MSB method modified by Zerbino-Lukasevich.

Results: In microvessels, there were changes in the walls associated with alcohol coagulation of their structures. The lumens of arteries and arterioles were occluded with "shadows" of red blood cells or with small blood clots, which caused ischemic damage to CMC. Alcohol leakage beyond the capillaries was accompanied with coagulation necrosis of the surrounding CMC. 10 hours after ASA, WBC infiltrates were present in the affected areas.

Key words: hypertrophic cardiomyopathy, interventricular septum, alcohol ablation, morphology. 